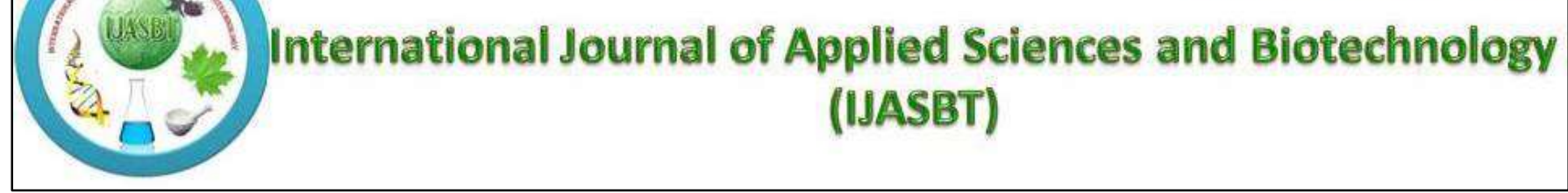

Research Article

\title{
GROWTH AND PRODUCTIVITY OF DIFFERENT CULTIVARS OF RICE UNDER NUTRIENT EXPERT@ AND OTHER FERTILIZER MANAGEMENT PRACTICES AT LAMJUNG
}

\author{
Achyut Gaire*, Samjhana Koirala, Ram Kumar Shrestha and Lal Prasad Amgain
}

Tribhuwan University, Institute of Agriculture and Animal Science, Lamjung Campus, Nepal

\begin{abstract}
Corresponding author's email: itthomanes01@gmail.com
Abstract

Rice is an important world leading cereal crop grown extensively in tropical and sub-tropical regions of the world. However, its productivity is constrained by a number of problems. Currently, cereal yields are only 40 to $65 \%$ of their potential, mostly because nutrient management does not consider crop's dynamic response to the environment and site specific nutrition management. Therefore, a field experiment was conducted on farmer's field at Lamjung, Sundarbazar and Bhoteodar using Nutrient Expert® rice model from July 2015 to November 2015. Four replications of 5 treatments were arranged in randomized complete block design. Five treatments were Nutrient Expert recommendation (NE hybrid), Government recommendation (GR hybrid), NE improved, GR improved and Farmers field practice (FFP). The result revealed significant difference in terms of plant height, panicle weight, filled grain/panicle, straw yield, grain yield at $15.5 \%$ moisture, biological yield and sterility \%.The highest yield (7.362tonha-1) was obtained from NE hybrid field which was followed by GR hybrid (6.12tonha-1), NE improved (5.20tonha-1), FFP (4.76tonha-1) and GR improved (4.70tonha-1). While comparing Nutrient Expert $(\mathrm{NE})$ estimation for attainable rice yield with actual rice yield from the farmer field trial; NE-based fertilizer recommendations proved to be successful in reaching the yield targets estimated by the software. The actual rice yields recorded in farmer fields were higher than the NE estimated attainable yields, so NE recommendation was found better over GR and FFP.
\end{abstract}

Keywords: Farmers Practice; Government Recommendation; Hybrid Rice; Improved Rice; Nutrient Expert

\section{Introduction}

The rice is the most widely grown cereal crop and is stable food for more than half of the world's population. It is mostly grown in lowlands under fully irrigated or rain-fed conditions. It is estimated that $90 \%$ of world's area, production and consumption of rice are in Asia. Rice was grown over about 163 million ha in the entire world. It was reported that out of total world rice production of 719 million tons, 590 million tons was produced in Asia (FAOSTAT 2013) that is why it is said "Rice brings the Asians together ". In context of Nepal, the crop is grown in all the three major agro-ecological regions i.e. Terai and Inner Terai, Hills and Mountains. The area, production and productivity of paddy in Nepal is 1.43 million ha, 4.8 million tons $\mathrm{ha}^{-1}$ and 3.17 ton $\mathrm{ha}^{-1}$ respectively (Statistical information on Nepalese agriculture 2013/14). 20\% of agricultural gross domestic product is contributed by rice alone. The cultivated area under rice in the Lamjung district is 16.45 thousand ha, while the average yield is $2.86 \mathrm{t} \mathrm{ha}^{-1}$ (MoAD, 2012/13).
Agriculture is an important sector in the Nepalese economy, contributing to about a third of its GDP and engaging about two-thirds of its population (MoAC, 2013). Agriculture is mostly rain-fed and dominated by subsistence farming systems. Rice production, amounting to about half of the total cereal grains produced in the country, is Nepal's most important crop (Ghimire et al., 2013). Out of total cultivated land of Nepal, Only about $40 \%$ is irrigated. Majority of farmers still depend upon the rain water for rice cultivation. Rain-fed lowland rice is grown in nearly $49 \%$ of the total rice growing areas in the country. The crop is grown at the altitude ranging from 60 to 3,050 masl. From all altitude points of view, 3,050 masl, is the highest place where rice is grown in the world. JumliMarshi is one of the best cold tolerant local rice varieties, which is grown in the high altitude of Nepal. Rice is cultivated in the diverse ecoclimatic ranges of Nepal at differing altitudes, topography, climate, in floods, deep water, waterlogged land, drought, in problem soil and with weed infestation, with disease and pests. 
Population growth and the increase in the demand for food, on the one hand, and insufficient growth in farm productivity, on the other, have turned Nepal gradually from a food-exporting country to a food-importing country within a few decades (Pokhrel, 2013). There is great difference in yield between developed countries and Nepal which may be due to depletion of organic matter, imbalance use of fertilizer, intensive cropping without inclusion of legumes crops in rotation, monoculture, use of traditional varieties, nutrient leaching with monsoon rain, lack of knowledge of new inputs and technologies to farmers etc. There is large gap between crop yield potential and farmers' yields. The lower yield persists in the farmer's field mainly due to the improper fertilizer management. Of all external inputs required for crop production in Nepal, nutrients are the most limiting factor. In reliable and predictable rainfall environments and under assured irrigation conditions with proper control of pests and diseases, nutrients become the most limiting factor.

In context of our country, existing fertilizer recommendations by government bodies and research stations consist of fixed rates of $\mathrm{N}, \mathrm{P}$, and $\mathrm{K}$ for vast areas without considering the site-specific soil and weather conditions which has resulted in under-fertilization in some areas and over fertilization in others. In most cases, there is low use of all nutrients while in some cases relatively high use of nitrogen (N) and phosphorus (P) and low use of potassium $(\mathrm{K})$, secondary and micro-nutrients. The growth and needs of a crop for supplemental nutrients are actually not constant and can instead vary among fields, seasons, and years as a result of differences in crop-growing conditions, crop and soil management, and climate. Such imbalanced and inadequate use of nutrients can decrease the nutrient use efficiency (NUE) and profitability and may increase environmental risks associated with loss of unutilized nutrients through emissions or leaching. In addition, considerable yield gaps exist between researcher managed optimum NPK plots and farmers' fertilizer practices (Ladha et al., 2003), indicating a great opportunity for increasing rice yield and productivity through improved nutrient management practices.

Site-specific nutrient management is a set of nutrient management principles that aims to supply a crop's nutrient requirements tailored to a specific field or growing environment. Its purpose is to (a) account for indigenous nutrient sources, including crop residues and manures; and (b) apply fertilizer at optimal rates and at critical growth stages to meet the deficit between the nutrient needs of a high-yielding crop and the indigenous nutrient supply. Nutrient Expert is a new, computer-based decision support tool that helps crop advisers formulate fertilizer guidelines based on SSNM principles. NE considers the most important factors affecting nutrient management recommendations in a particular location and enables crop advisers to provide farmers with fertilizer guidelines that are suited to their farming conditions.

The tool uses a systematic approach of capturing site information that is important for developing a locationspecific recommendation. Yet, NE does not require a lot of data nor very detailed information as in the case of many sophisticated nutrient decision support tools, which could overwhelm the user. It allows users to draw the required information from their own experience, the farmers' knowledge of the local region, and the farmers' practices. NE can use experimental data, but it can also estimate the required SSNM parameters using existing site information.

Thus we have conducted this research for the first time in mid hills of Nepal using NE tool for identifying the best way of rice nutrient management for sustained higher yield under different climatic and edaphic parameters in collaboration with International Plant Nutrient Institute (IPNI), Non-residence Nepalese Association (NRNA) Australia and Institute of Agriculture and Animal Sciences (IAAS) Lamjung.

\section{Materials and Method}

This research was held in Lamjung district in collaboration with NRNA (Australia), IPNI (Delhi) and IAAS, Lamjung. Four farmers of Bhoteodar and Sundarbazar vdcs were selected randomly. Preliminary survey was done with the Nutrient Expert questionnaire. The information was collected from the farmers and simulated attainable yield for each farmer field was obtained by using the Nutrient Expert ${ }^{\circledR}$ software. Randomized Complete Block Design with 5 treatments and 4 replications were set up. Five treatments were NE hybrid (Nutrient Expert recommendation), GR hybrid (Government recommendation), NE improved, GR improved and FFP (Farmers Field Practices). Gross plot size of $100 \mathrm{~m}^{2}$ for each treatment and net plot size of $5 \mathrm{~m} 2$ (from where all yield attributing data was taken) was maintained.

Table 1: Average values of initial soil fertility at research sites in Lamjung (2015).

\begin{tabular}{lllll}
\hline Site & Samples & $\mathbf{p H}$ & $\begin{array}{l}\text { Available } \mathbf{P}_{2} \mathbf{O}_{5} \\
\left(\mathbf{k g ~ h a}^{-1}\right)\end{array}$ & $\begin{array}{l}\text { Available } \mathbf{K}_{2} \mathbf{O} \\
\left(\mathbf{k g ~ h a}^{-1}\right)\end{array}$ \\
\hline $\begin{array}{l}\text { Bhotewodar-Lamjung } \\
\text { Sundarbazaar-Lamjung }\end{array}$ & Soil (3.05\% OM) & 5.9 & 103.2 & 210.5 \\
\hline
\end{tabular}




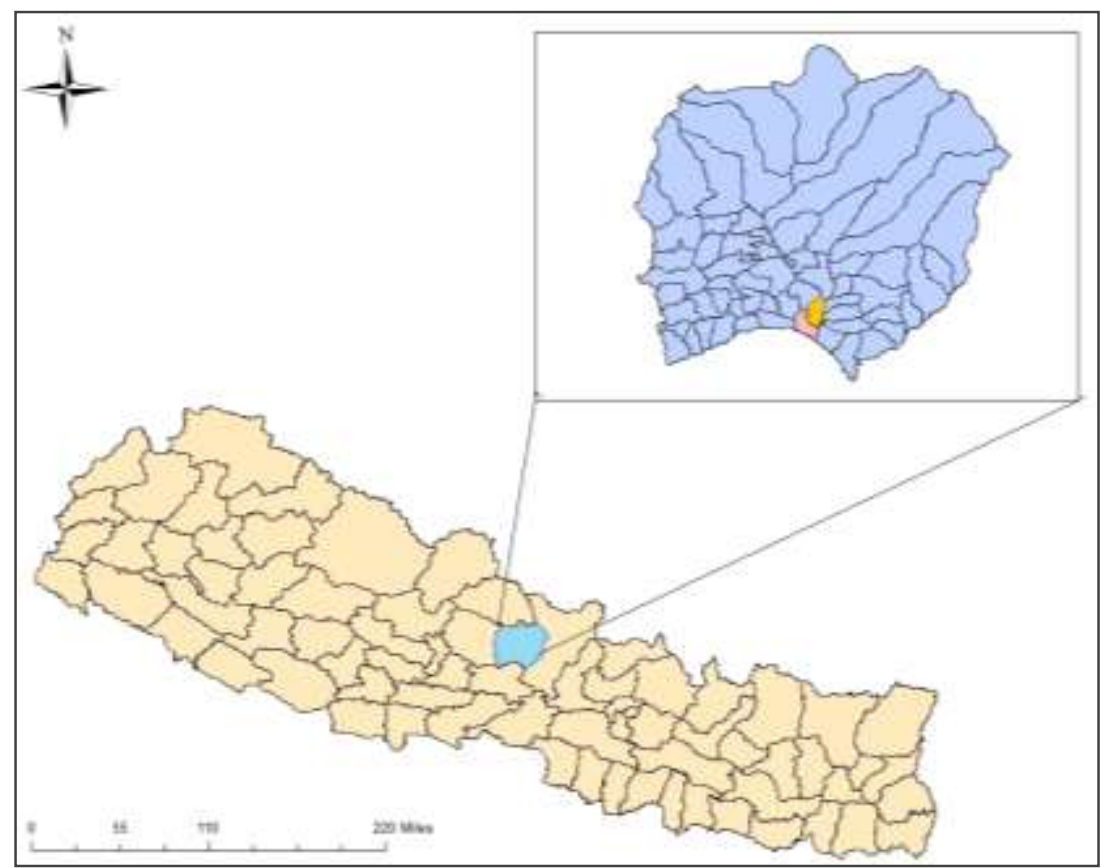

Fig. 1: Experimental site at Lamjung district, Nepal.

Hybrid rice US382 and Improved rice; Ramdhan was transplanted from $17^{\text {th }}$ July2015in farmer field according to the treatment set-up. Harvesting was done from 17th -19 th November, 2015. Observation on plant ht, effective and non-effective tiller per hill, Leaf Area Index, panicle weight, panicle length, filled and unfilled grain, biological yield, straw yield, yield at $15 \%$ (tonha $^{-1}$ ) was taken. Gross plot size of $100 \mathrm{~m}^{2}$ for each treatment was maintained in each farmer's field. The actual rice yield was taken from net area of $10 \mathrm{~m}^{2}$.

Comparison of Nutrient Expert® (NE) estimated attainable rice yield by the software with actual rice yield from the farmer field trial was done. Data entry and analysis was done using; Microsoft word for data processing, MS excel for data input, table, charts, graphs \& simple statistical analysis, SPSS Statistics 21, Gens Stat 2003 for statistical analysis. ANOVA was done at $0.05 \%$ level of significance.

\section{Results and Discussion}

\section{Plant Height}

From the Table 2, highly significant result was observed for plant height taken at harvest. The longest plant height was

Table 2: Effect of different nutrient management in growth and yield attributing characters of rice in Lamjung, Nepal.

\begin{tabular}{|c|c|c|c|c|c|c|c|c|}
\hline Treatment & $\begin{array}{l}\text { Plant height } \\
\text { at harvest }\end{array}$ & $\begin{array}{l}\text { Panicle } \\
\text { wt }\end{array}$ & $\begin{array}{l}\text { Filled Grain } \\
\text { panicle }^{-1}\end{array}$ & $\begin{array}{l}\text { Grain } \\
\text { Yield } \\
\left.(\mathbf{t ~ h a})^{-1}\right)\end{array}$ & Sterlity & $\begin{array}{l}\text { Straw } \\
\text { Yield } \\
\left(\mathrm{t} \mathrm{ha} \mathbf{~ h}^{-1}\right)\end{array}$ & $\begin{array}{l}\text { Biological } \\
\text { Yield }\left(\mathrm{t} \mathrm{ha}^{-1}\right)\end{array}$ & $\begin{array}{l}\text { Harvest } \\
\text { Index }\end{array}$ \\
\hline $1 \mathrm{NE} \mathrm{H}$ & $103.2 \mathrm{a}$ & $5.452 a$ & $157.10 \mathrm{~b}$ & $7.362 \mathrm{a}$ & $16.65 b$ & $9.935 \mathrm{a}$ & $17.298 \mathrm{a}$ & $42.40 \mathrm{ab}$ \\
\hline 2NE I & $86.08 \mathrm{~cd}$ & $2.735 b$ & $90.07 \mathrm{c}$ & $5.20 \mathrm{~b}$ & $27.94 a$ & $7.376 b c$ & $12.57 \mathrm{bc}$ & $41.71 \mathrm{ab}$ \\
\hline 3GR H & $102.3 \mathrm{ab}$ & $5.702 \mathrm{a}$ & $205.75 a$ & $6.12 b$ & $14.57 b$ & $8.728 \mathrm{ab}$ & $14.85 \mathrm{ab}$ & $41.12 b$ \\
\hline 4GR I & $78.95 \mathrm{~d}$ & $2.372 b$ & $82.25 c$ & $4.70 \mathrm{~b}$ & $27.70 \mathrm{a}$ & $6.204 c$ & $10.90 c$ & $42.79 \mathrm{ab}$ \\
\hline $5 \mathrm{FFP}$ & $91.72 b c$ & $3.095 b$ & $111.77 \mathrm{c}$ & $4.76 b$ & $20.61 \mathrm{ab}$ & $5.517 \mathrm{c}$ & $10.28 \mathrm{~d}$ & $46.91 \mathrm{a}$ \\
\hline Sig & $* *$ & $* *$ & $* *$ & $* *$ & $* *$ & $* *$ & $* *$ & $*$ \\
\hline S Em & 24.351 & 0.642 & 290.352 & .154 & 15.951 & 1.119 & 0.675 & 1.431 \\
\hline $\operatorname{LSD}(0.05)$ & 7.6 & 1.23 & 26.25 & 0.6047 & 6.154 & 1.55 & 2.080 & 4.411 \\
\hline CV\% & 5.8 & 22.9 & 13.9 & 18.7 & 11.4 & 9.7 & 12.8 & 7.5 \\
\hline
\end{tabular}




\section{Sterility Percentage}

Significant difference between different treatments was found in case of percentage sterility. The highest $\%$ sterility was obtained in field of improved variety under NE (27.9\%) followed by treatment GR improved (27.7\%), FFP (20.61\%), NE hybrid (16.65\%) and GR hybrid (14.57\%).

\section{Grain Yield per Hectare}

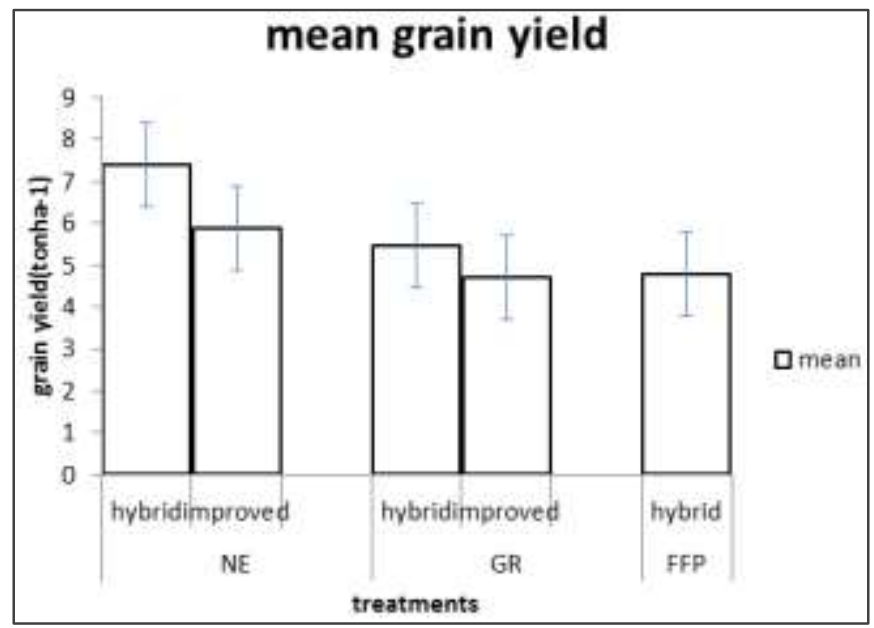

Fig. 2 Average grain yield at $15 \%$ moisture.

7.362 tonha $^{-1}$ of grain yield adjusted at $15.4 \%$ moisture was obtained under NE hybrid which was the greatest yield among different treatments followed by hybrid under GR $\left(6.1 \mathrm{tha}^{-1}\right)$, improved under NE $\left(5.2 \mathrm{ha}^{-1}\right), \operatorname{FFP}\left(4.8 \mathrm{ha}^{-1}\right)$ and improved under GR (4.7 ha-1) (Fig 2). Rice yields were far more stable and varied within a short range as the NE recommendation for each individual farmer was designed to achieve the maximum attainable yield of HYVs of rice in the monsoon season (Virmani et al., 2003). Studies using
NE for other crops like maize and wheat also showed significant yield advantage from the NE-based fertilizer recommendation as compared to existing practices (Regmi, 2003; Pampolino et al., 2012; Sapkota et al., 2014). Dobermann et al. (2004) also reported similar results that the SSNM practice in rice across Asia resulted in higher yields than the FFP.

\section{Straw Yield per Hectare}

All the treatments of nutrient management showed the significant results for straw yield. The highest straw yield $\left(9.9 \mathrm{t} \mathrm{ha}^{-1}\right)$ was obtained under hybrid variety with $\mathrm{NE}$ followed by hybrid with GR $\left(8.72 \mathrm{t} \mathrm{ha}^{-1}\right)$, improved variety of NE (7.37 tha-1), improved variety with GR $\left(6.2 \mathrm{t} \mathrm{ha}^{-1}\right)$ and FFP $\left(5.3 \mathrm{t} \mathrm{ha}^{-1}\right)$. Straw yield is a function of vegetative growth and balanced and optimum use of fertilizer increased plant height, leaves hill ${ }^{-1}$, tillers hill ${ }^{-1}$ and dry matter production, which finally resulted in higher straw yield. Similar results were reported by Virmani et al. (2003), Srivastava et al. (1987).

\section{Biological Yield}

Highest Biological yield was obtained in the NE Hybrid field i.e. (26.68 t/ha) which was at par with GR Hybrid field i.e.(23.09 t/ha).Lowest biological yield was obtained in the farmers practices i.e (15.01t/ha).Higher yield was due to right dose of fertilizer recommendation and application at right time.

\section{Harvest Index}

HI was found to be highest under FFP (46.91) followed by GR improved (42.79), hybrid under NE (42.40), NE improved(41.71), hybrid under GR(42.79) respectively.

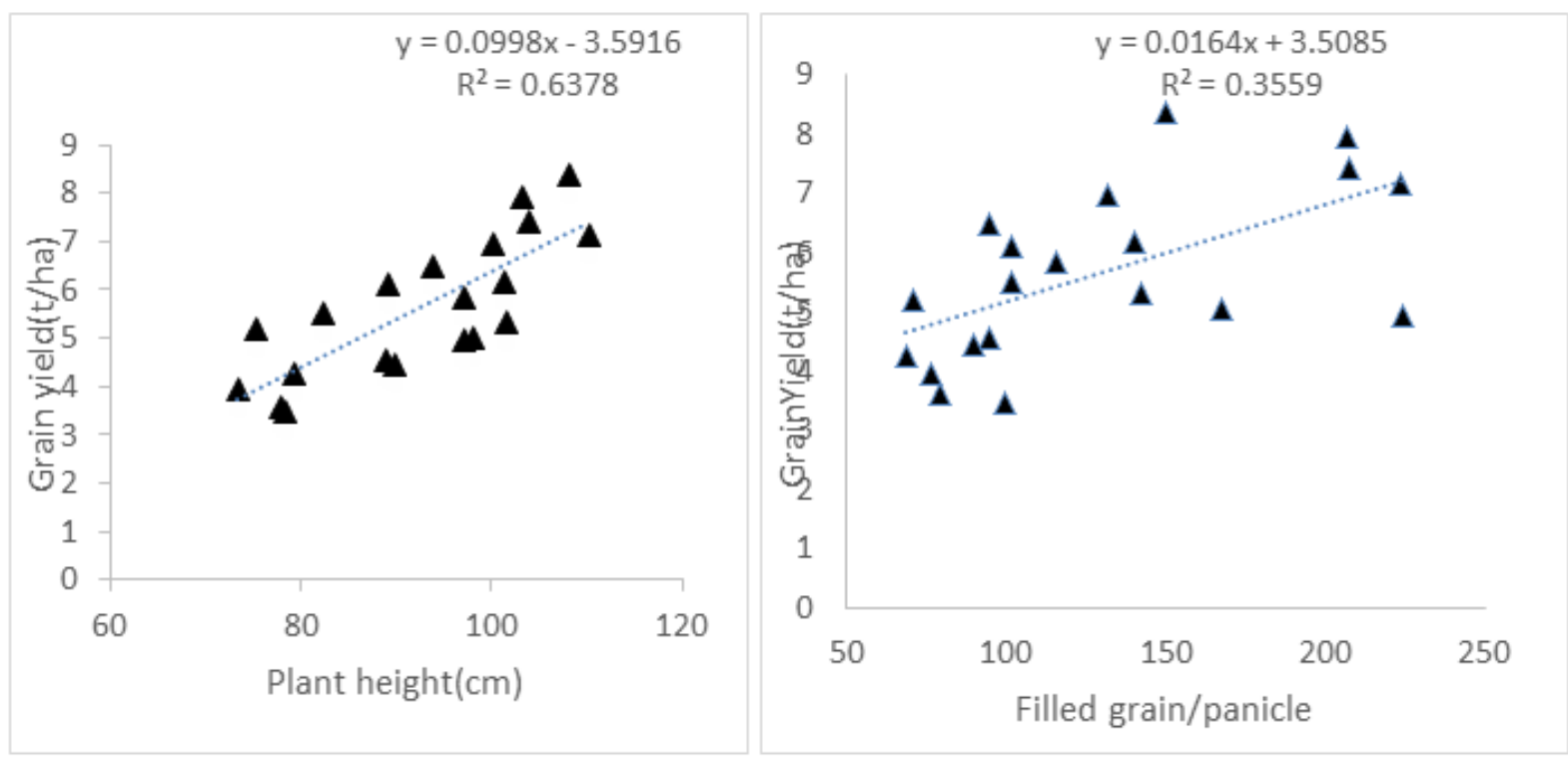

Fig. 3: Relationship of grain yield with plant height at harvest and filled grains/panicle. 


\section{Conclusions}

The above discussed growth and yield parameters of rice proved that the site specific nutrient management under NEbased fertilizer recommendations were found better over GR and FFP in terms of yield as a result of balanced fertilization and application of right source of fertilizer at right place and time in right amount. Moreover in comparision to hybrid and improved varieties, hybrid ones under NE -based fertilizer recommendation gives significantly higher yield. The tool was able to capture the inherent differences between conventional and conservation practices of crop management and site specific nutrient recommendations from NE rice performed better than GR and FFP for rice. Water management, crop establishment, and pest management must be finetuned to fully exploit the improved plant nutrition potential. If better control of factors other than $\mathrm{N}, \mathrm{P}$, and $\mathrm{K}$ is achieved, SSNM will probably become a key component for yield increases up to about $80 \%$ of the yield potential of currently available varieties, which is equivalent to the average farm yields needed by 2020. Although performance differences were large among sites, SSNM can be considered a low-risk technology for most environments. So the further testing of the NE -Rice is required with multi-location trials in different agro-ecological regions of Nepal to develop confidence and for its wider applicability.

\section{References}

Dobermann A, Witt C and Dawe D (2004) Increasing productivity of intensive rice systems through Site-Specific Nutrient Management. Science Publishers, Inc., International Rice Research Institute, Enfield, N.H. (USA) and Los Baños (Philippines).
Ghimire S, Dhungana S, Krishna VV, Teufel N and Sherchan DP (2013) Biophysical and socio-economic characterization of cereal production systems of Central Nepal. Socioeconomics Program Working Paper 9. Mexico, D.F., CIMMYT.

Haq MT, Sattar MA and Hasain MM (2002) Effects of fertilizers and pesticides on growth and yield of rice. Online Journal of Biological Sciences 2(2): 84-88. DOI: $10.3923 /$ jbs.2002.84.88

Ladha JK, Dawe D, Pathak H, Padre AT, Yadav RL and Singh B (2003) How extensive are yield declines in long-term ricewheat experiments in Asia? Field Crops Res. 81: 159-180. DOI: 10.1016/S0378-4290(02)00219-8

Pampolino M, Majumdar K, Jat ML, Satyanarayana T, Kumar A, Shahi VB, Gupta N and Singh V (2012) Development and evaluation of Nutrient Expert for Wheat in South Asia. Better Crops. 96(3): 29-31.

Pokhrel TP (2013) Rice development programme in Nepal. http://www.fao.org/docrep/v6017t/V6017T04.htm

Regmi AP (2003) Improving the productivity of rice-wheat system through field specific nutrient management in Nepal. Thesis (Ph.D.) University of the Philippines at Los Banos (UPLB), Los Banos, Laguna, Philippines.

Salam MA, Fouzia L, Kabirand MH and Khan AR (2011) Effect of different doses of fertilizers on yield and yield components of two varieties of bororice. J. Agro. Environ. 5(2): 53-56.

Sapkota TB, Majumdar K, Jat ML, Kumar A, Bishnoi DK, McDonald AJ and Pampolino M (2014) Field Crops Res.155: 233-244. DOI: 10.1016/j.fcr.2013.09.001

Virmani SS, Mao CX and Hardy B (2003) Hybrid rice for food security, poverty alleviation, and environmental protection. International Rice Research Institute. pp. 265286. 